\title{
From model minorities to disposable models: the de-legitimisation of educational success through discourses of authenticity
}

\author{
Alice Bradbury
}

\begin{abstract}
This article explores teachers' use of discourses of authenticity in relation to minoritised students, with a focus on the relationship between these discourses and 'model minority' status. The paper aims to advance the critical thinking about 'model minorities' in the education system in England by examining the diversity of identity positions and minoritised groups that can be constituted as belonging to this category in different contexts. It is argued that in England there is 'intelligible space' for some students from the Afghan and Kosovan communities to be constituted as 'model minorities', alongside the Chinese and Indian communities usually identified with this term, with similar links made between the home lives of students and their educational attainment. However, this status carries with it racist assumptions about students' motivation, and the perception of high attainment as inauthentic and therefore illegitimate. Building on Archer and Francis' (2007) discussions of Chinese students' success as being achieved in the 'wrong way', it is argued that the idea of (in)authenticity can be used to delegitimise educational success in multiple ways. Data from two qualitative research projects in primary and secondary schools in England is used to demonstrate how multiple discourses of inauthenticity can be deployed in ways which render minoritised students' success as illegitimate because it is predicated on external factors, in contrast to an implicit idealised White student whose success is due to inherent characteristics. A theoretical framework influenced by Critical Race Theory is used to discuss the role of this partial and precarious recognition of some minoritised groups' high attainment in the continuation of White dominance in education. (224 words)
\end{abstract}

\section{Introduction}

This article aims to develop two related discussions in the field of race and education concerning the constitution of some groups as 'model minorities' and the use of discourses of authenticity to dismiss minoritised students' attainment. This discussion is motivated by the need to examine in more detail the limits of 'model minority' status and to emphasise the multiplicity of ways in which 
the attainment of minoritised students can be rendered illegitimate. This is a combination of effects which, it is argued, allows for the continued idealisation of White students and their successes and the maintenance of the status quo in terms of disparities in educational attainment. Data from qualitative research based in Primary (age 5-11) and Secondary (age 11-16) schools in London is used to illustrate the widening groups of students who may be intelligibly understood as 'model minorities', and the range of ways in which their educational successes are rendered inauthentic. The analysis is informed by tools offered by Critical Race Theory (CRT), which illuminate how changing classroom discourses can work at a systematic level to maintain long-standing racial disparities.

The article begins with a discussion of 'model minority' discourses and the related issue of authenticity based on research in the UK and international educational contexts. A second section examines the theoretical tools offered by CRT and their use in this discussion, before a description of the research studies which gave rise to the data used. The following sections and organised around the two main arguments proposed: first, that 'model minority' status is fluid and has, in the English context, expanded to include smaller minoritised groups identified as having a good 'education ethic'; and secondly, that all forms of 'model minority' status are accompanied by multiple concurrent dismissals of educational success in the form of discourses of inauthenticity. A final section examines the role of this partial and precarious recognition of some minoritised groups' high attainment in the continuation of White dominance in education, and the lessons for those who wish to challenge this state of affairs.

\section{'Model minorities'}

The discussion of model minorities in this paper builds on David Gillborn's examination of this concept, which has origins in the United States, in the UK context in his book 'Racism and Education: Coincidence or conspiracy?' (Gillborn, 2008). Of particular relevance is his argument that there is 'a disposable character to model minorities' (2008: 146); a fluidity in which groups of pupils can be intelligible as 'model'. Gillborn argues that some groups may no longer be seen as 'model' when they 'no longer serve the interests of powerholders'; following this argument, this paper considers who may be added to the list of model minorities when this serves some purpose.

The term 'model minority' has a longer history in the US than the UK, and is usually applied there to 'Asian Americans', particularly the Chinese and Japanese communities'. According to Li and Wang's history of the term, the first use dates back to a 1966 New York Times article on Japanese Americans 
(2008: 3). This was followed by a US News and World Report on the success of Chinese Americans (cited in Pang and Palmer, 2012: 1518), and a 1971 article in Newsweek discussing how some minority groups were 'outwhiting the whites' (Li and Wang, 2008:3). The emergence of this stereotype has to be seen within the changing racial dynamics of the Civil Rights era, and the historic and continued constitution of Asian-Americans as Other; as a New York Times commentator reminds us in a reflective piece on 30 years since the racist murder of Vincent Chin, 'history [...] teaches us that before Asian-Americans were seen as model minorities, we were also perpetual foreigners' (Wu, 2012).

Within the 'model minority' discourse, which has remained persistent into the twenty-first century, Asian Americans are stereotyped as displaying 'proper behaviours and attitudes (e.g. uncomplaining and docile) and proper work ethics (e.g. hardworking, persistent, diligent, and self-abnegating)' (Li, 2008: 216); students from this community are essentialised as 'whiz kids' (Lee, 2008:IX). Chang and Au list the characteristics of the 'model minority' student as 'devoted, obedient to authority, respectful of teachers, smart, good at math and science, diligent, hard workers, cooperative, well behaved, docile, college-bound, quiet and opportunistic' (p15). This is an infantilising discourse, which positions Asian-Americans - in school and beyond - as dependent on their parents and lacking in agency. The stereotype had been fuelled, Min (2004) argues, by statistics showing that Asian Americans have a higher median family income than White Americans, although this a flawed measure skewed by higher average family sizes (Change and Au, 2007).

Although some Asian Americans have accepted and explored this 'model' status (see discussion in Li and Wang) many scholars have rejected the term as 'complimentary on its face' but 'disingenous at its heart' (Wu, 2002 cited in Li and Wang, 2008:2). The term is a 'bomb cloaked in sugar', as it positions Asian Americans as 'perpetual foreigners and/or honorary whites' (Li and Wang, 2008:5). Extensive scholarship in this area has shown that there are multiple negative consequences of being positioned as a 'model minority', including the invisibility of racism against Asian Americans and a dismissal of claims of prejudice. Yamada (1981, cited in Chang, 2000:359) gives an example of how university students reacted angrily to an anthology of 'outspoken Asian American writers', whom they saw as militant although they had been sympathetic to literature from other minoritised groups; for Asian Americans to complain of racism, it seemed, was going too far. The stereotype disguises structural inequalities suffered by Asian Americans; Min points out that although Asian Americans have higher levels of attainment overall, they do not receive equal rewards for their educational investments; their success in school does not necessarily translate into higher incomes or more rewarding careers (Min, 2004). At the same time, the status of Asian Americans as 'model' 
can cause resentment from other minority communities and from the White majority, concerned that Asian Americans 'crowd out places for Whites in the classroom and workplace' by winning scholarships and increasing grade averages (Li, 2008:219). The consequences of this discourse can also be significant for those students who do not fit the stereotype, including those have special educational needs, whose barriers to learning may be not be recognised (Lo, 2008; Li, 2008); as Guofang Li argues 'If we blindly measure students against the stereotypes, we run the risk of ignoring their needs and overlooking their strengths' (2008:228). Furthermore, beyond the impact of the community under discussion, there is also an impact on wider discussions of racism and other minoritised groups, a topic which is discussed in more detail later on in this paper. The construction of successful Asian Americans, Min argues 'legitimates the supposed openness of American society' (2004:334), with consequences for other groups. Moreover, as Stacey Lee argues, there can be 'no "model minority" without the concomitant stereotype of the lazy and unintelligent Black or Brown other' (Lee, 2008:IX). 'Model minorities' thus function as a discursive tool to deny accusations of racism and divert attention from continuing racial inequities.

In the UK, and more specifically England, the term 'model minority' has more recently been applied to different communities, namely the Indian and Chinese communities (Gillborn, 2008), due to their high levels of attainment in standardised national tests through the 1990s and 2000s. However, it would be wrong to suggest that the emergence of this discourse is due only to availability of statistics; it is based on far more complex understandings of the place of the Indian and Chinese communities within the multiplicity of migrant groups in the UK. In the case of Indian students, educational success has been linked to the supposedly middle-class occupations of many migrants from India in the post-war period, through perceptions of an appropriate 'education ethic'. There is certainly an important class dimension to this discourse - the proportion of students from these groups in receipt of free school meals are similar to the White British majority-although this is sometimes denied by those who seek to compare the Indian and Chinese students' success with other minoritised students' levels of attainment (Gillborn, 2008:147). This class-based analysis of differential attainment is also recognisable in the academic literature; for example, the argument of Chang and Au that differences within the wide Asian-American group can be explained by 'the first rule of educational inequality [...]: Class matters' (2007: 16).

In England, pervasive discourses which link parental attitudes and students' home lives to inevitable paths of educational attainment or failure, both linked to and separate from class explanations, are powerful in the operation of the 'model minority' discourse. Qualitative research on British Chinese students' experiences by Archer and Francis (2007) found that were understood by teachers as 
hardworking and successful in education, but were also subject to racist discourses of 'Chinese geeks'. British Chinese families were seen as too 'pushy' and students were homogenised through 'oppressive expectation' and pathologised as too focused on school at the expense of other activities. Despite their successful learner identities, British Chinese students' stereotyped subservience and passivity were criticised by teachers, leading to a 'negative positive', where teachers had high expectations based on racist assumptions (Archer and Francis, 2007). As in research in the United States, there were consequences for the British Chinese students' experiences of education.

Other than Gillborn's CRT-informed analysis, there has been little academic discussion of the 'model minority' discourse in education in England, despite its prevalence in discussions of racism in schools (Archer and Francis do not use the term in their research on British Chinese students). As Gillborn argues, the fact that Indian and Chinese students attain higher scores in exams at age 16 than White British students (the government's term) is frequently cited as evidence that the education system is not institutionally racist. This argument is predicated on the idea that a system must be racist to all minority groups, or none at all; it denies the fact that racist assumptions may work in contradictory ways, and may have different effects on different groups. It also suggests that if a system (or indeed an individual) is racist, then they must be so equally to all groups, when this is patently not the case. A system may discriminate against one minority group while leaving another apparently unaffected. Underlying this 'racist to all or none' argument, I would argue, is a persistent conception of racism as individual prejudice manifested in explicitly racist actions, which refuses to accept the impact of unwitting actions on minoritised groups' experiences and attainment. This denial of the idea that racism can be systematic without intention and indeed institutional is a major barrier to progress in anti-racist work in the UK. This paper seeks to open up discussion of the discourse of model minorities, by exploring the fluidity of who is constructed as 'model' and emphasising the negative elements of this status, particularly the denial of authenticity. In doing so, this aim is to further reduce the impact of the 'racist to all or none' argument as a denial of institutional racism in education.

\section{The research studies}

The data used in this article arose from two studies, both conducted in London in the period 20092011. First, I use data from an ESRC-funded research project involving long-term ethnographic studies of two Reception classrooms (children aged 4-5) in inner London. The schools, which I call Gatehouse and St Mary's primary schools, were located in an economically deprived area of London and the majority of the children in these two classes were from minoritised communities. The study 
involved classroom observation over the course of a year and regular interviews with the Reception teachers; the overall findings are discussed in detail elsewhere (Bradbury, 2011; 2012; 2013). The second study, funded by the London Educational Research Unit at the Institute of Education, was a small pilot project exploring the experiences and attainment of students from the Afghan community in London. This involved background research on the community and semi-structured interviews with a primary school teacher (children aged 5-11) and a secondary teacher (ages 11-16) in schools with high numbers of Afghan pupils. These schools were located in a different area of London.

Data from both of these studies were coded using NVivo and analysed using a theoretical framework influenced by Critical Race Theory and also by post-structural theory, including Foucault's conception of discourse and Butler's use of performative identities (Butler, 1993; 2004). In particular, Butler's theories of recognisable identities are used to examine which discourses need to be deployed to allow particular groups of children to be intelligible as students, and in this case the 'intelligible space' required for these students to be constituted as 'model minorities'. Davies, using Butler's work, argues that 'Subjects, and this includes school students, who are constituted as lying outside intelligibility are faced with the constitutive force of a language that grants them no intelligible space' (Davies, 2006:434); this lack of intelligibility is a significant theme in the discussion of authenticity in the later section of this article. Drawing on Critical Race Theory, I use the principle of interest convergence (Bell, 2003) to examine the purpose of 'model minorities' in the continuance of white dominance. Simply put, this principle suggests that gains are only made when they serve white interests; this is a useful starting point for the consideration of why some groups become constituted as 'model'. I also build upon on Gillborn's (2008) CRT-inspired discussion of 'disposable minorities', who may only be temporarily constituted positively but serve some purpose.

\section{The fluidity of 'model minorities'}

One the central ideas of CRT and much other literature on 'race' is the historicity of the social construct of race - that racisms and racial terms are flexible and serve the political interests of the time. Omi and Winant's (2004) 'racial formation' approach, which takes neither a 'race as illusionary' nor a 'racial objectivist' position, takes into account 'the importance of historical context and contingency in the framing of racial categories and the social construction of racially defined experiences' (p11). Thus the relative positions of different groups within popular discourse are dependent on the expediencies of a particular time and place; the movement of different communities into and out of 'model minority' status (a status which is entirely constructed rather 
than an actual phenomenon, I should emphasise) is further indication of the fluidity with which racebased stereotypes can operate to maintain the status quo. I argue, using data from London schools, how students from a number of smaller Muslim communities from Afghanistan, Iraq, Kosovo and elsewhere have access to 'model minority' status alongside their Indian and Chinese counterparts. I comment here only on the situation in the UK, and only speculatively given the scale of the data used; nonetheless, this data raises questions regarding the overall assumption that 'Muslim' students are constituted negatively in schools in England (Shain, 2010), and the idea that 'model minority' status is fixed.

Previous discussion of 'model minorities' in England has included discussion of groups of students who temporarily move into 'model' status, as mentioned. Gillborn's (2008) examination of the positioning of students from Monserrat who arrived in the UK after being evacuated following a volcanic explosion found these students were initially lauded in the national press as part of criticism of the school system. However, using in the work of Gertrude Shotte, a Montserratian headteacher who researched the experiences of the students, Gillborn argues that in long term the educational experiences and attainment of the Montserratian students were low and a disproportionate number were excluded from school (2008:159). Gillborn's discussion of these 'disposable models' also reminds us of the subjectivity of 'model minority' status; his discussion is based on one Mail on Sunday newspaper article, which had an alternative agenda, and unfortunately there is little research on how the Monserratian students were received in schools initially. It may be that these students were never 'model' to the schools involved and experienced racism from the very start of their time in the UK education system. Nonetheless, what this discussion emphasises is the way in which the use of discourses of 'model' students, however temporary, serves some interest other than that of the group itself. In this case, this interest is the denigration of the school system, but in wider terms, 'model minorities' provide evidence of a supposed meritocratic system in which any student can achieve.

\section{Model minorities in Reception}

The flexibility of 'model minorities' was evident in the Reception classrooms of young children I researched in inner London. In these classrooms some minoritised children, and girls in particular, were held up as 'model' students and in turn their families and communities were positioned as 'model minorities' (see also Bradbury, 2013)ii. At one school, which I call Gatehouse, five students from the Afghan and Kosovan communities were the highest attaining girls in the teacher's assessment ${ }^{\mathrm{iii}}$, alongside a White working-class girliv. They were also held up as examples for the other students, and chosen for special tasks requiring sensible behaviour. These students were constituted as hardworking, well-behaved, and conscientious; their teacher described one Afghan 
girl, Khadija, as 'amazing, kind of, just funny and "how do you know that?" kind of girl'. As with the research on Chinese students, this 'model' status was linked explicitly and implicitly to their families' attitudes and aspirations. In this fieldnote, the staff are discussing a new student, Farah, who would go on to become the highest attaining pupil in the class:

The teachers are discussing a new pupil after a home visit: the new girl is described as "quite bright, quite a bit of English". They hope the new girl will be good model of English for the other children. She is described as Afghan and Pashto speaking. They discuss if there are any other Afghan children. The class teacher mentions that older children in the family have gone to university and says "obviously they have high aspirations". The family is also described as very "with it"; Dad took time off work to meet Farah's new teacher. (Fieldnotes, Gatehouse)

From the very beginning of her first year in school, before she even enters the classroom, Farah's nascent 'model' identity and the link with her family are established. Similarly, discussions of Khadija, the student mentioned above as 'amazing' included references to her father's job at a broadcasting organisation, such as 'obviously [he] talks about stuff at home'. This link with children's families' attitudes toward education was also mentioned in the other Reception classroom, where the teacher commented on what he saw as a hierarchy of different groups in terms of their 'education ethic':

'In my last school it was a lot of Kurdish children, who'd come from villages, whose parents didn't know what... They really weren't that interested in education to be honest, and so they did no work with them at home. [...] Those children seriously didn't move the way that some of our Arab-speaking children from Baghdad, whose parents have fleed the country but are very highly educated, who can't speak much English, but they've got high education ethic.' (Class teacher, St Mary's)

In this teacher's view, the children who had left the city of Baghdad during conflict were preferable to the Kurdish children from villages because of the two communities' different parental attitudes; this is similar to the way in which the justification of Indian students' success is often the assumed middle-class origins of their families.

The data from the second project on Afghan pupils suggests that this model status and the connection with family attitudes is present in relation to this specific group more widely: the primary teacher interviewed made the following comments: 
'The pupils themselves are very keen, behaviour is never really an issue. They're kind of wideeyed and very respectful and very well behaved. They respond to the opportunities of school very well.'

'We assume that [...] if they've managed to get out of a war-torn area like Afghanistan they must have the means and the wherewithal. [...] They are aspirational for their children, they understand that education is going to be the key way out.' (Primary Teacher)

As in the Reception classrooms in the first study, the Afghan students are constituted as 'model', well-behaved, keen to learn and eager to make the most of 'the opportunities of school'. This last phrase is also indicative of a neoliberal discourse of individual responsibility for success which, as much of the US literature on model minorities points out, locates responsibility for differential success firmly with the student and family and not with the school system. Like the Reception teacher's comments on Iraqi families above, these children's assumed escape from a conflict zone is taken as an indication of both middle-classness and aspiration; their refugee status is seen as a barrier to be overcome through education, and the wider structural inequalities faced by these communities are ignored. The secondary teacher interviewed also commented positively on her teenage Afghan students' attitudes toward school, saying they were 'Pretty motivated, they all have that in common'. She made explicit comparisons with the British Indian community in the school and commented that 'that kind of cultural aspirational desire to achieve well academically is something throughout the school'. Both teachers made comments that identified the Afghan students as (relatively) middle class. The primary teacher said 'They are probably middle class, whatever that means for the Afghan community', while the secondary teacher explained how an Afghan student had told her that it was 'people with money, not necessarily the wealthiest in society, but you know people with access to money, could afford to escape the country'.

As I have explained, it is not clear whether students from the Afghan, Kosovan and Iraqi communities are more widely constituted as 'model' and the lack of available data on the attainment levels of these students ${ }^{\vee}$ (and more detailed qualitative research) makes such a claim only tentative. However, there is some purpose in considering how these students are intelligible as 'model' to these teachers, and what this means for the operation of 'model minority' discourses more widely. Using Butler's ideas of intelligible subjects who are constituted through discourse (Butler, 1993; 2004), and following Youdell's (2006) work on intelligible student-subjecthood, we can explore how some students can become recognisable as successful learners, albeit temporarily. I would argue that these students from smaller Muslim minority communities which originated in countries which have experienced recent conflict are constituted as 'model' through a web of 
discourses relating to good/bad migrants, assimilation, class and religious moderation. Their assumed 'middle classness' (not equivalent to White middle classness however, as I discuss below) resonates with wider discourses relating to the connection between income levels and attainment, middle-class parenting styles and a positive 'education ethic'. At the same time, neoliberal individualist discourses of responsibility with an emphasis for on 'upward mobility' applied in the past and present to working-class children (Walkerdine, 2003) make the discourse of aspiration among minoritised communities more potent. Assimilationist discourses of 'good migrants' who have aspirations and are hardworking and keen to adopt 'Western' values, which are present in a policy context of 'contemporary assimilationism' (Gillborn, 2008), position these families as acceptable minorities in general.

More specifically for the girls, discourses of 'Asian' pupils as passive and obedient (Shain, 2003; Connolly, 1998) and girls' success in the education system overall, make their high attainment and good behaviour intelligible within educational discourse. Furthermore,, in a context of increased Islamophobia and the regular connection of Iraq and Afghanistan in particular with Muslim extremist violence in popular discourse, these families who have come to the UK are positioned as models of a kind of submissive, assimilating, liberal and Westernised Islam which is acceptable and welcomed. This is an important final point, given the tendency in the UK to use a binary notion of 'Asian' communities (a term which may or may not include some of the communities under discussion here) divided into 'good' Indian/Hindu and 'bad' Pakistani/Bangladeshi/Muslim (Archer and Francis, 2007:42). Within the Muslim communities there is a wide variety of different groups (including those not included within an 'Asian' category) and there is a danger that discussion of 'Muslim students' homogenises a wide array of students into a singular, negative identity. Thus it is important to emphasise that not all Muslim students are understood negatively in schools; in fact, through this complex set of discourses, some Muslim children are intelligible as 'model' minoritised students.

A key element of the 'model minority' discourse is the constitution of an entire community as successful, not just individuals within that perceived racial group. Although some of the data here do suggest this is the case, this is an argument requiring further research and exploration. Furthermore, some of these schools may be atypical in terms of the absence or small numbers of White students. However, these data suggest that there is some 'intelligible space' for other groups of students to be constituted as 'model minorities' in the current context in England. This is particularly the case where these groups provide a contrast to other minorities who are seen to have less positive attitudes toward education or lower attainment. As I discuss further below, the fluidity of 'model minority' status, although it may offer some benefit to some students who have access to high 
expectations and positions of success (however temporarily) principally serves to maintain the status quo in terms of White dominance in education. I now turn to what I see as the sharper side of the double-edged sword of 'model minority' status, the dismissal of high attainment as inauthentic.

\section{Multiple discourses of (in)authenticity}

As in the US literature on Asian Americans in schools, the research on British Chinese students has identified the notions of 'pushy parents', overwork and unnecessary pressure in teachers' perceptions. In Archer and Francis' study, British Chinese students' success was seen as having been 'achieved in the wrong way' and their parents' enthusiasm for learning was described by teachers as 'aggressive, producing the "wrong sort" of learning, being too "enclosed" and denying children individuality' (2007:42). This discourse of inappropriate parental pressure among Chinese communities is familiar in the public domain, and has more recently been discussed explicitly with the debate surrounding the publication of 'Battle Hymn of the Tiger Mother' by Amy Chua, a guide to 'ultra-strict' parenting (Chua, 2011). In the US, the model minority myth has led to the marketing of books revealing the 'secrets' of Asian American parenting (Chang and Au, 2007). There are parallels between the discussion of British Chinese students and Youdell's research findings that Indian students were constituted as diligent and successful 'but not intrinsically gifted' (Youdell, 2006:143). In schools, I would argue, this discourse of success through mere hard work and as a result of parental pressure can be applied to a wider range of students and works powerfully to render these young people's successes inauthentic. The idea that high attainment among some minoritised students is caused by 'overwork' or external parental pressure has as its counterpoint the idea that White students' successes are caused by something innate and internal; a White normative ideal is implicit, I would argue, in this dismissal of some students' success as inauthentic.

I use the term authenticity as a shorthand for this complex discourses, as it arises both in Archer and Francis' analysis and independently in the data I collected in Reception classrooms (see the quote below). This discussion builds upon previous work on teachers' descriptions of girls' learning styles, particularly in masculine subjects, as not the 'proper way' (Walkerdine, 2003), although two decades on the associations of gender and success are perhaps altered (Renold and Allan, 2006). With regard to authenticity, Archer and Francis conclude:

The 'ideal learner' is an inherently embodied discourse which always excludes minority ethnic pupils and denies them from inhabiting positions or identities of 'success' with any sense of permanency or authenticity' (Archer and Francis, 2007:170) 
For the British Chinese students in their study, the association of their success with overwork and parental pressure meant that although they were constituted as 'model', they could not be positioned as ideal authentic learners. A similar analysis applies to the successful children from range of minoritised communities in the Reception classes I observed. In both classrooms, discourses of authenticity were used to delegitimise the attainment of minoritised students; here, the class teacher at St Mary's is discussing 'thinking skills':

"They all, there are some children who are very good at repeating, and memorising, but in terms of real thinking skills: not really there. [...] So you get what I mean, there are a lot of children who have learned a lot, but they haven't intellectually got that thinking skills and problem solving. [...] There are too many children coming out that are able to repeat things, like a parrot, or follow a writing frame ... they'll do that but ask them to really truly do something authentic and they can't do it and I think that's a major problem." (Class teacher, St Mary's)

For this teacher, there is a clear distinction to be made (which he can identify) between repetition, memorising or following a writing frame, and something 'authentic'. This discourse, which places the responsibility for assessing authenticity with the teacher, can work as a refusal to recognise educational success in various forms, for any student. In the other Reception classroom I studied, the same discourse of skills which were 'not really there' was used to question the attainment of one the 'model' Afghan girls discussed earlier in this paper, Khadija. Although her class teacher had described her as 'amazing' earlier in the year, when it came to placing the children in groups based on 'ability', Khadija was placed in the second group of five. When I discussed the groups with the class teacher, he explained that "She's very vocal, but she's there for consolidation. I'm not sure it's all there". As I have discussed in more detail elsewhere (Bradbury, 2013), this was part of a wider shift in Khadija's learner identity, a central part of which was the rendering of her success as inauthentic. She was not the only student to be dismissed in this way: another Afghan girl, Bilqis, was initially praised by the staff as the only child in the class who could read all the required 'high frequency words', a list of words which the curriculum requires Reception children to recognise instantly. However, she remained in a lower 'ability' group for reading because, her class teacher explained, "Her mum has been working flat out since she joined Reception" to teach her these words. This achievement, just like that of the British Chinese students, was deemed to be entirely due to parental pressure rather than an inherent skill.

This discourse of authenticity has its roots in a model of an ideal student, a subject which has occupied a range of literature (Becker, 1952; Gillborn, 1990; Youdell, 2006). The idea that some 
learning is not authentic cannot exist without the idea that some is authentic. The problem is that the authentic ideal appears to only be possible and intelligible for the White student, leaving the successes of minoritised students unrecognised. Furthermore, authenticity is not simply about academic achievement; it can be used to dismiss a wider range of 'good student' characteristics. In the Reception classes I observed, discourses of authenticity also applied to behaviour and attitudes: some children were seen as being naturally well-behaved, and others as putting on a show of good behaviour. Others were seen as taking part in activities because their enthusiasm for learning was a natural trait, while other children were seen as merely trying to please the teacher. Thus perceptions of a 'performance' of good learning could be used to demean students' wider attributes, beyond their academic attainment.

Authenticity discourses also have a complex relationship with ideas about innate intelligence and the organisation of education on the basis of 'ability'. On many occasions, as in the quote about repetition and memory above, authenticity is linked to innate intelligence and contrasted with a lack of inherited 'ability'. But it is important to note that some students from minoritised communities are constituted as inherently 'able' or intelligent; some teachers in Archer and Francis' study described their Chinese students as 'clever', for example. But this intelligence is often described as being linked to the racial group; thus it becomes another essentialising characteristic based on biological notions of 'race', while simultaneously demeaning the achievement of the individual. At the same time, notions of achieving in the 'right way' can continue to delegitimise attainment, even if students are seen as intelligent.

Thus far, this discussion has focused on discourses of authenticity based on parental pressure and attainment which is 'not all there'. In this final section I want to consider another facet of authenticity, which was deployed in discussions of teenage Afghan children's attainment. In an interview with a teacher in a London secondary school with a number of Afghan students, clear distinctions were made between the motivations of successful Indian students and successful Afghan students. Although, as mentioned, motivation was seen as something all the students had in common, the teacher explained that for the Afghan students 'motivation comes from more within themselves than from parental expectations'. She went on to say:

'I think that kind of psychological impact of having to flee your country, essentially as a refugee, has kind of affected their identity in a way that for another student it may not have the same effect' (Secondary teacher) 
Several of this teacher's Afghan students had come from Afghanistan without their families and/or in traumatic circumstances; this was linked, it appeared, to her sense of their motivation. I would argue that this explanation is another form of dismissal through inauthenticity. These students' motivation and success is attributed to being a refugee and needing to use education as a 'way out' (like the Afghan parents' views mentioned by the primary teacher). It is based on a kind of 'refugee mentality' and not, implicitly, due to their intelligence. These students' success is delegitimised through a slightly romanticised notion of a lone teenage refugee struggling against the odds, which resonates with wider ideas about 'good migrants' and their aspirations. I would argue, albeit tentatively given the limits of these data, that this is an alternative form of the authenticity discourse, which instead of linking success to parental pressure, bases inauthenticity on a need for escape. Authenticity, being in the eye of the beholder, is a flexible concept which can be re-deployed in multiple forms. This difference between the data from Reception and Primary classrooms and the Secondary teacher in relation to Afghan students, this 'model Muslim' minority, is perhaps due to the age of the students involved. Nonetheless what it does point to is the multiplicity and complexity of discourses of authenticity and how they can be deployed to dismiss minoritised attainment.

\section{Discussion}

A central argument of this paper is that in the education system in England, discourses of 'model minorities' and 'authenticity' are flexible, and can be used to delegitimise the academic successes of minoritised communities. These two discourses are intertwined, and one works to resolve the other: model minorities are useful in denying claims of institutional racism based on 'racist to all or none' assumptions, but their success is achieved in the 'wrong way'. If a wider range of minoritised groups including Afghan, Iraqi and Kosovan students begin to be constituted as 'model' (and again, I reiterate this is certainly not a universal or widely used discourse yet), discourses of inauthenticity based on parental pressure and a 'refugee mentality' can be used to dismiss this. Furthermore, assumptions that certain minoritised families are 'pushy' linked to inauthenticity are the basis for 'model minority' status, which leads to the argument that the system cannot be racist. Together, these ideas work powerfully to maintain a White idealised norm and deflect attention from raced disparities in attainment.

What this discussion has not considered is the wider picture, which includes the significant problem of the lower attainment of many minoritised groups. Using a CRT framework, I want to explore what purpose model minorities serve in the wider maintenance of White dominance in education. A wellused theoretical tool in CRT is Bell's principle of interest convergence (Bell, 2003), which argues that gains made by the Black community in the US are only those which serve White interests. Bell argues 
that the Brown vs. Board of Education decision to desegregate schools was motivated by foreign policy interests; there was a convergence of interests, not a desire to reduce racial inequality. Although the issue of model minorities and authenticity discussed here is not an example of interest convergence, some of the ideas have some resonance with the concept. There is a sense with model minorities of having given something up (White groups at the top of attainment statistics) for the continuation of the wider project of White dominance. But while something is lost, the fundamentals are maintained through dismissals based on authenticity; Whiteness is still idealised, associated with authentic intelligence and educational success. As in interest convergence, what is gained is only partial and only occurs when it serves White interests.

Based on this argument, why would additional groups gain access to 'model' status? The concept of interest convergence suggests that the minimum is only ever conceded. Furthermore, as Gillborn notes, 'it does not matter who provides the model as long as there is a model to point to' (2008:157), and Chinese and Indian high attainment in England continues to provide this model. Even if their positions are not as prominent as these two communities (and are limited by the statistics available), why would other groups be intelligible as 'model'? Perhaps there is some purpose in positioning some smaller Muslim minorities as model, while the majority Pakistani and Bangladeshi Muslim minorities continue to be pathologised in what Youdell (2003) in a different context has called a 'hierarchy of the Other'. In a context of concern over Islamophobia, perhaps a version of the usual 'model minority' argument, a 'racist to all Muslim groups or none' position, is useful in denying accusations of racism. There is a need for a good/bad binary in discussions of all groups: perhaps what we see in the positive descriptions of Afghan, Iraqi and Kosovan students is the emergence of a 'good Muslim'/'bad Muslim' division, similar to the division of British Asians into good/Indian/Hindu and bad/Pakistani/Bangladeshi/Muslim in the 90s and 2000s. Research from the US on Asian Americans has provided examples of a similar binary within the 'model' Asian-American group: Lee has argued that in some contexts Asian-Americans are discursively divided into passive high-achieving 'good kids' and 'bad kids', who were 'Americanised' Hmong students who adopted a 'hip hop style associated with urban youth of color' (Lee, 2005, cited in Li and Wang, 2008:7), for example. What remains potent in all these possibilities, both in the UK and US, is the centrality of the White ideal, as the measure against which all groups will be compared. It is also important not to overstate the planned or intentional nature of shifting boundaries of 'model' status, and to reiterate the difference between this case and examples of interest convergence from legal studies; however, there is some utility, I would argue, in considering how changing patterns of how, to adapt Gillborn's phrase, 'racism plays favourites' (Gillborn, 2008:153) and what ends this serves. 
The roles played by 'model minorities' and discourses of authenticity serve as useful reminders of continued White dominance. For all minoritised students, 'model' or not, these discourses continue to locate the source of disparities with students and families, not with the education system. 'Model minorities' deflect attention from continued educational difference in the UK and elsewhere, while students from these communities continued to be subject to racist assumptions of inauthentic learning. One of the tensions in discussions of 'model minorities' lies between the need to reduce the idea to the status of myth, and recognising the very real impact of this myth on the lived experiences of both people from that minority and those from other minoritised groups. Although it may have its advantages, as Chang argues, to accept that some minorites are 'model' is to be 'complicitous in the oppression of other racial minorities and poor whites' (2000:361). But while it exists and becomes established - and the US is a cautionary tale for the UK in this respect - it must be challenged and questioned.

\section{References}

Archer, L. and Francis, B. (2007). Understanding minority ethnic achievement: debating race, gender, class and 'success'. London: Routledge.

Becker, H. S. (1952). 'Social-class variation in the teacher-pupil relationship'. Journal of Educational Sociology, 25 (8), 451-465.

Bell, D. (2003) The Derrick Bell Reader New York: New York University Press

Bradbury, A. (2011). 'Rethinking assessment and inequality: the production of disparities in attainment in early years education'. Journal of Education Policy, 26 (5), 655 - 676.

Bradbury, A. (2012). 'Education policy and the "ideal learner": producing recognisable learnersubjects through assessment in the early years'. British Journal of Sociology of Education.

Bradbury, A. (2013). Understanding Early Years Inequality: policy, assessment and young children's identities. London, Routledge.

Butler, J. P. (1993). Bodies that matter: on the discursive limits of "sex". London: Routledge.

Butler, J. P. (2004). Undoing gender. New York: Routledge. 
Chang, R. (2000) 'Towards an Asian American Legal Scholarship: CRT, Post-structuralism and Narrative Space' in Delgado, R. and Stafancic, J. (eds) (2000) Critical Race Theory: the Cutting Edge ( ${ }^{\text {nd }}$ Edition). Philadelphia: Temple University Press

Chang, B., \& Au, W. (2007). You're Asian, how could you fail math?: Unmasking the myth of the model minority. Rethinking Schools, 22(2), 15-19

Chua, A. (2011) Battle Hymn of the Tiger Mother London: Bloomsbury

Connolly, P. (1998). Racism, gender identities and young children: social relations in a multi-ethnic, inner-city primary school. London: Routledge.

Davies, B. (2006). 'Subjectification: the relevance of Butler's analysis for education'. British Journal of Sociology of Education, 27 (4), 425-438.

Delgado, R. and Stafancic, J. (eds) (2000) Critical Race Theory: the Cutting Edge (2 ${ }^{\text {nd }}$ Edition). Philadelphia: Temple University Press

Gillborn, D. (1990). 'Race', ethnicity and education: teaching and learning in multi-ethnic schools. London: Unwin Hyman.

Gillborn, D. (2008). Racism and education: coincidence or conspiracy? London: Routledge.

Lee, S. (2008) 'Foreword' in Li, G. and Wang, L. (eds) (2008) Model Minority Myth Revisited: An Interdisciplinary Approach to Demystifying Asian American Educational Experiences. Charlotte: Information Age Publishers

Li, G. (2008) 'Other people's success: impact of the 'model minority' myth on underachieving Asian students in North America' in Li, G. and Wang, L. (eds) (2008) Model Minority Myth Revisited: An Interdisciplinary Approach to Demystifying Asian American Educational Experiences. Charlotte: Information Age Publishers

Li, G. and Wang, L. (eds) (2008) Model Minority Myth Revisited: An Interdisciplinary Approach to Demystifying Asian American Educational Experiences. Charlotte: Information Age Publishers

Lo, L. (2008) 'Interactions between Chinese parents and special education professionals in IEP meetings: implications for the education of Chinese immigrant children with disabilities' in Li, G. and Wang, L. (eds) (2008) Model Minority Myth Revisited: An Interdisciplinary Approach to Demystifying Asian American Educational Experiences. Charlotte: Information Age Publishers 
Min, P. G. (2004) 'Social Science Research on Asian Americans' in Banks, J. and Banks, C. (eds) (2004) Handbook of Research on Multicultural Education, (2 ${ }^{\text {nd }}$ edition). San Francisco: Jossey-Bass

Omi, M. and Winant, H. (2004). 'On the Theoretical Status of the Concept of Race'. In G. LadsonBillings and D. Gillborn (Eds), The RoutledgeFalmer reader in multicultural education: critical perspectives on race, racism and education. London: RoutledgeFalmer.

Pang, V. and Palmer, J. (2012) 'Model Minorities' in Banks, J. (ed) (2012) Encyclopedia of Diversity in Education. London: SAGE

Renold, E. and Allan, A. (2006). 'Bright and Beautiful: High achieving girls, ambivalent femininities, and the feminisation of success in the primary school'. Discourse: studies in the cultural politics of education, 27 (4), 45-473.

Shain, F. (2003). The schooling and identity of Asian girls. Stoke on Trent: Trentham Books.

Shain, F. (2010). The New Folk Devils: Muslim boys and Education in England. Stoke-on-Trent: Trentham.

Shain, F. (2010). The New Folk Devils: Muslim boys and Education in England. Stoke-on-Trent: Trentham.

Walkerdine, V. (2003). 'Reclassifying Upward Mobility: femininity and the neo-liberal subject'. Gender and Education, 15 (3), 237 - 248.

Wu, H. (2012) 'Why Vincent Chin Matters' in New York Times, 22 June 2012, available at: http://www.nytimes.com/2012/06/23/opinion/why-vincent-chin-matters.html?_r=0 [Last accessed 27 March 2013]

Youdell, D. C. (2003). 'Identity traps or how black students fail: the interactions between biographical, sub-cultural and learner identities'. British Journal of Sociology of Education, 24 (1), 3-20.

Youdell, D. C. (2006). Impossible bodies, impossible selves: exclusions and student subjectivities. Dordrecht: Springer.

\footnotetext{
'To clarify, I use the term Asian-American (sometimes referred to Asian Pacific American) in the sense that it is used in the US; the term 'Asian' in the UK is usually used to refer to the Indian, Pakistani and Bangladeshi
} 
communities, not the Chinese community. In reference to the UK I avoid the term, except when citing research which uses this terminology.

ii These classes included only two or three White students, and few or no students from the Chinese or Indian communities, which may be relevant here.

iii This teacher assessment, which is a standardised system across Reception classrooms in England, is conducted through observation and, as I have argued elsewhere, is not a true measure of what children can or cannot do. It is, however, a measure of what a teacher expects a child to be able to do (within the constrictions of a performative accountability system), and therefore is an indication of these students' 'model' status.

iv It is worth noting that some of the literature on Asian American students makes use of the concept of 'honorary Whites'; which I do not use but may be relevant here. In particular, there is scope for further exploration (which I do not have space for here) of the status of Kosovan children, who are listed in official document as White European, but are nonetheless a minoritised group in contrast to the White British majority.

' The UK Department of Education publishes data by 'ethnic group' but not in a form that allows the consideration of the attainment of these smaller groups. 